\title{
PENGARUH CORPORATE GOVERNANCE TERHADAP NILAI PERUSAHAAN PADA PERUSAHAAN PERBANKAN YANG TERDAFTAR DI BEI TAHUN 2011-2014
}

\author{
Andy Meindarto ${ }^{1}$, Fitri Lukiastuti ${ }^{2} \bowtie$ \\ STIE Bank BPD Jateng Semarang \\ ${ }^{1}$ e-mail: andymeindarto@ymail.com \\ 2 e-mail: flaluki@yahoo.com
}

\begin{abstract}
This study aims to determine the effect of corporate governance on corporate value with the quality of earnings as an intervening variable. Corporate governance mechanism uses four variables managerial: ownership, institutional ownership, the proportion of independent directors and audit committee. The sample consist of 28 banking companies in 2011-2014. The research used Multiple Linear Regression Analysis to test the influence of independent variables on dependent variable. Varible of earnings quality that measured by $D A$ (Discretionary Accrual) has effect on firm value. Institutional ownership of independent board and audit committee have effect on earning quality. Other variables such managerial ownership and institutional ownership have no effect on earnings quality. Institutional ownership and independent board have effect on firm value, meanwhile managerial ownership and the audit committee have no effect on firm value. The value of adjusted $R^{2}$ for the effect of corporate governance mechanisms on the quality of earnings was 0.170 or $17 \%$. While the value of adjusted $R^{2}$ for the effect of corporate governance mechanisms on firm value with the quality of earnings as an intervening variable was 0.311 or $31.1 \%$.
\end{abstract}

Keywords: corporate governance, managerial ownership, institutional ownership, the proportion of independent board, audit committee, earnings quality, corporate value

\begin{abstract}
Abstrak
Penelitian ini bertujuan untuk mengetahui pengaruh corporate governance terhadap nilai perusahaan dengan kualitas laba sebagai variabel intervening. Mekanisme corporate governance menggunakan empat variabel yaitu kepemilikan manajerial, kepemilikan institusional, proporsi komisaris independen dan komite audit. Penelitian menggunakan sampel 28 perusahaan perbankan tahun 2011-2014. Metode penelitian adalah Analisis Regresi Linier Berganda dengan hasil penelitian kualitas laba yang diukur dengan DA (Discretionary Accrual) berpengaruh terhadap nilai perusahaan. Variabel yang berpengaruh terhadap kualitas laba adalah dewan komisaris independen dan komite audit. Variabel lainnya yaitu kepemilikan manajerial dan kepemilikan isntitusional tidak berpengaruh terhadap kualitas laba. Untuk variabel yang
\end{abstract}


berpengaruh terhadap nilai perusahaan yaitu kepemilikan institusional dan dewan komisaris independen, sedangkan variabel yang tidak mempunyai pengaruh terhadap nilai perusahaan adalah kepemilikan manajerial dan komite audit. Nilai adjusted $R^{2}$ untuk pengaruh mekanisme GCG terhadap kualitas laba sebesar 0.170 atau $17 \%$. Sedangkan nilai adjusted $R^{2}$ untuk pengaruh mekanisme GCG terhadap nilai perusahaan dengan kualitas laba sebagai variabel intervening yaitu sebesar 0.311 atau $31,1 \%$.

Kata kunci: corporate governance, kepemilikan manajerial, kepemilikan institusional, proporsi dewan komisaris independen, komite audit, kualitas laba, nilai perusahaan

\section{PENDAHULUAN}

Penilaian investor terhadap perusahaan pada dasarnya dapat diamati melalui pergerakan harga saham yang sedang ditransaksikan di bursa efek. Investor bersedia membeli saham perusahaan dengan harga tinggi jika perusahaan tersebut memang benar-benar mempunyai prospek yang bagus dan dapat memberikan return sesuai dengan besarnya investasi yang telah mereka keluarkan. Banyak investor mengalami kesulitan dalam memprediksi nilai perusahaan sebagai salah satu acuan dalam pengambilan keputusan investasi disebabkan harga saham perusahaan mengalami kenaikan maupun penurunan. Kenaikan maupun penurunan harga saham dapat disebabkan oleh beberapa faktor, faktor internal seperti kenaikan laba bersih, kinerja keuangan perusahaan, dan rencana ekspansi, ataupun faktor eksternal seperti tingkat suku bunga, nilai tukar mata uang rupiah, harga saham, kebijakan pemerintah, dan pengaruh dari bursa luar negeri.
Para calon investor yang ingin berinvestasi sebaiknya harus memiliki pengetahuan, kemampuan, dan kejelian dalam menilai perusahaan sehingga sesuai dengan harga saham yang sedang diperjualbelikan. Apabila perusahaan melakukan investasi yang bersifat spekulatif, ada kecenderungan harga saham akan turun karena risiko usahanya menjadi semakin besar. Dengan demikian total kemakmuran pemegang saham dapat diukur dengan menilai peningkatan total kepemilikan saham dikalikan dengan harga pasar per lembar saham. Maka semakin tinggi harga pasar saham berarti kemakmuran pemegang saham semakin meningkat (Sartono, 2010). Harga pasar saham juga menunjukkan nilai perusahaan, apabila harga saham dari perusahaan naik maka dapat meningkatkan nilai perusahaan, dan sebaliknya jika harga pasar saham mengalami penurunan maka nilai perusahaan akan menurun karena ada tanda-tanda bahwa kinerja perusahaan tersebut sedang ada masalah. 
Pengaruh Corporate Governance terhadap Nilai ... (Andy Meindarto \& Fitri Lukiastuti)

Tabel 1. Daftar nilai PBV Perbankan (tahun 2011-2014)

\begin{tabular}{|c|c|c|c|c|}
\hline \multirow[b]{2}{*}{ Nama Perusahaan } & \multicolumn{4}{|c|}{ PBV } \\
\hline & $\begin{array}{c}\text { Tahun } \\
2011\end{array}$ & $\begin{array}{c}\text { Tahun } \\
2012\end{array}$ & $\begin{array}{c}\text { Tahun } \\
2013\end{array}$ & $\begin{array}{c}\text { Tahun } \\
2014\end{array}$ \\
\hline BRI agroniaga tbk. (AGRO) & 1.05 & 0.89 & 0.98 & 0.95 \\
\hline Bank MNC internasional tbk. (BABP) & 0.93 & 1.29 & 0.96 & 1 \\
\hline Bank Capital Indonesia TBK. (BACA) & 1.19 & 0.83 & 0.62 & 0.64 \\
\hline Bank Central Asia Tbk. (BBCA) & 4.69 & 4.32 & 3.7 & 4,33 \\
\hline Bank Bukopin Tbk. (BBKP) & 1.05 & 0.99 & 0.8 & 1.01 \\
\hline Bank Negara Indonesia (persero) tbk. (BBNI) & 1.87 & 1.59 & 1.54 & 1.86 \\
\hline Bank Nusantara Parahyangan Tbk. (BBNP) & 0.93 & 0.82 & 0.95 & 1,42 \\
\hline Bank Rakyat Indonesia (persero) Tbk. (BBRI) & 3.34 & 2.64 & 2.25 & 2.94 \\
\hline Bank Tabungan Negara (persero) Tbk. (BBTN) & 1.46 & 1.46 & 0.8 & 1.08 \\
\hline Bank Jtrust Indonesia Tbk. (BCIC) & 1.14 & 1.03 & 1.2 & 1.05 \\
\hline Bank Danamon Indonesia Tbk. (BDMN) & 1.52 & 1.88 & 1.15 & 1.31 \\
\hline Bank Pundi Indonesia Tbk. (BEKS) & 2.32 & 1.97 & 1.26 & 1.2 \\
\hline BPD Jawa Barat dan Banten Tbk. (BJBR) & 1.64 & 1.71 & 1.28 & 1.06 \\
\hline Bank Qnb Indonesia Tbk. (BCIC) & 2.83 & 2.85 & 1.83 & 1.57 \\
\hline Bank Mandiri (persero) Tbk. (BMRI) & 2.51 & 2.47 & 2.06 & 2.54 \\
\hline Bank Bumi Arta Tbk. (BNBA) & 0.67 & 0.73 & 0.64 & 0.64 \\
\hline Bank CIMB Niaga Tbk. (BNGA) & 1.67 & 1.22 & 0.89 & 0.74 \\
\hline Bank Internasional Indonesia Tbk. (BNII) & 2.97 & 2.36 & 1.52 & 1.1 \\
\hline Bank Permata Tbk. (BNLI) & 1.34 & 1.13 & 0.95 & 1.07 \\
\hline Bank Sinarmas Tbk. (BSIM) & 1.89 & 1.12 & 1.14 & 1.07 \\
\hline Bank of India Indonesia Tbk. (BSWD) & 1.5 & 3.62 & 1.24 & 1.78 \\
\hline Bank Tabungan Pensiunan Nasional Tbk. (BTPN) & 3.43 & 3.96 & 2.53 & 1.99 \\
\hline Bank Victoria Internasional Tbk. (BVIC) & 0.7 & 0.53 & 0.5 & 0.48 \\
\hline Bank Artha Graha Internasional Tbk. (INPC) & 0.71 & 0.49 & 0.46 & 0.38 \\
\hline Bank Mayapada Internasional Tbk. (MAYA) & 2.66 & 5.7 & 3.97 & 2.34 \\
\hline Bank Windu Kentjana Internasional Tbk. (MCOR) & 1.27 & 1.01 & 0.72 & 0.99 \\
\hline Bank Mega Tbk. (MEGA) & 2.62 & 1.93 & 2.33 & 2.07 \\
\hline Bank Ocbc Nisp Tbk. (NISP) & 1.15 & 1.46 & 1.05 & 1.08 \\
\hline Bank Pan Indonesia Tbk. (PNBN) & 1.18 & 0.86 & 0.8 & 1.21 \\
\hline Bank Woori Saudara Indonesia 1906 Tbk. (SDRA) & 1.08 & 2.89 & 3.57 & 4.63 \\
\hline
\end{tabular}

Sumber : www.idx.co.id.

Berdasarkan contoh pada tabel 1 di atas, nilai perusahaan yang diukur dengan menggunakan price book value (PBV) harga saham mengalami fluktuasi yang disebabkan oleh beberapa faktor mulai dari dampak krisis ekonomi yang sedang melanda atau perusahaan tersebut yang sedang mengalami penurunan kinerja keuangannya. Perusahaan diharapkan selalu mengalami peningkatan nilai perusahaan dari tahun ke tahun. Kenyataannya perusahaan yang berada di Indonesia sebagian besar memiliki nilai perusahaan yang kecil dan mengalami fluktuasi dari tahun ke tahun. Fluktuasi nilai perusahaan yang terlalu jauh dapat menimbulkan masalah, seperti perusahaan akan kehilangan daya tariknya di pasar saham (Purbopangestu, 2014). Semakin rendah nilai perusahaan maka semakin rendah 
pula minat investor untuk menanamkan modalnya. Nilai PBV yang di bawah 1 maka perusahaan tersebut telah mengalami masalah dalam kinerja perusahaan atau hal lainnya yang menyebabkan penurunan nilai perusahaan, dan sebaliknya perusahaan yang nilai PBV di atas 1 telah mengalami peningkatan kinerja perusahaan yang akan pula meningkatkan nilai perusahaan.

Dari gambar 1 terlihat bahwa nilai PBV 2011-2014 perbankan mengalami naik turun, dan kenaikan tertinggi dialami Bank Mayapada Internasional Tbk. Pada tahun 2012 sebesar 5,7 dan penurunan terendah dialami Bank Artha Graha internasional Tbk. Pada tahun 2014 sebesar 0,38. Dari data nilai PBV Bank Artha Graha Internasional tahun 2014 adalah yang terendah di antara lainnya, sehingga secara tidak langsung Bank Artha Graha Internasional tbk. kurang diminati investor. Dengan demikian bank yang nilai PBV nya lebih dari 1 lebih bisa dikatakan sehat secara finansial dan lebih memungkinkan untuk mendapatkan keuntungan dari pada bank yang nilai PBV nya di bawah 1 .

Bagi pemegang saham, laba berarti peningkataan nilai ekonomis (wealth) yang akan diterima melalui pembagian deviden, serta dianggap mempunyai informasi yang dapat menganalisis dan memprediksi saham yang diterbitkan oleh emiten. Laba juga digunakan sebagai alat untuk mengukur kinerja manajemen perusahaan selama periode tertentu yang pada umumnya menjadi acuan pihak-pihak tertentu terutama dalam menaksir kinerja atas pertanggung jawaban manajemen dalam pengelolaan sumberdaya yang dipercayakan kepada mereka, serta dapat digunakan untuk memperkirakan prospeknya di masa depan. Oleh karena itu informasi laba yang disajikan harus berkualitas (Sari dan Riduwan, 2013).

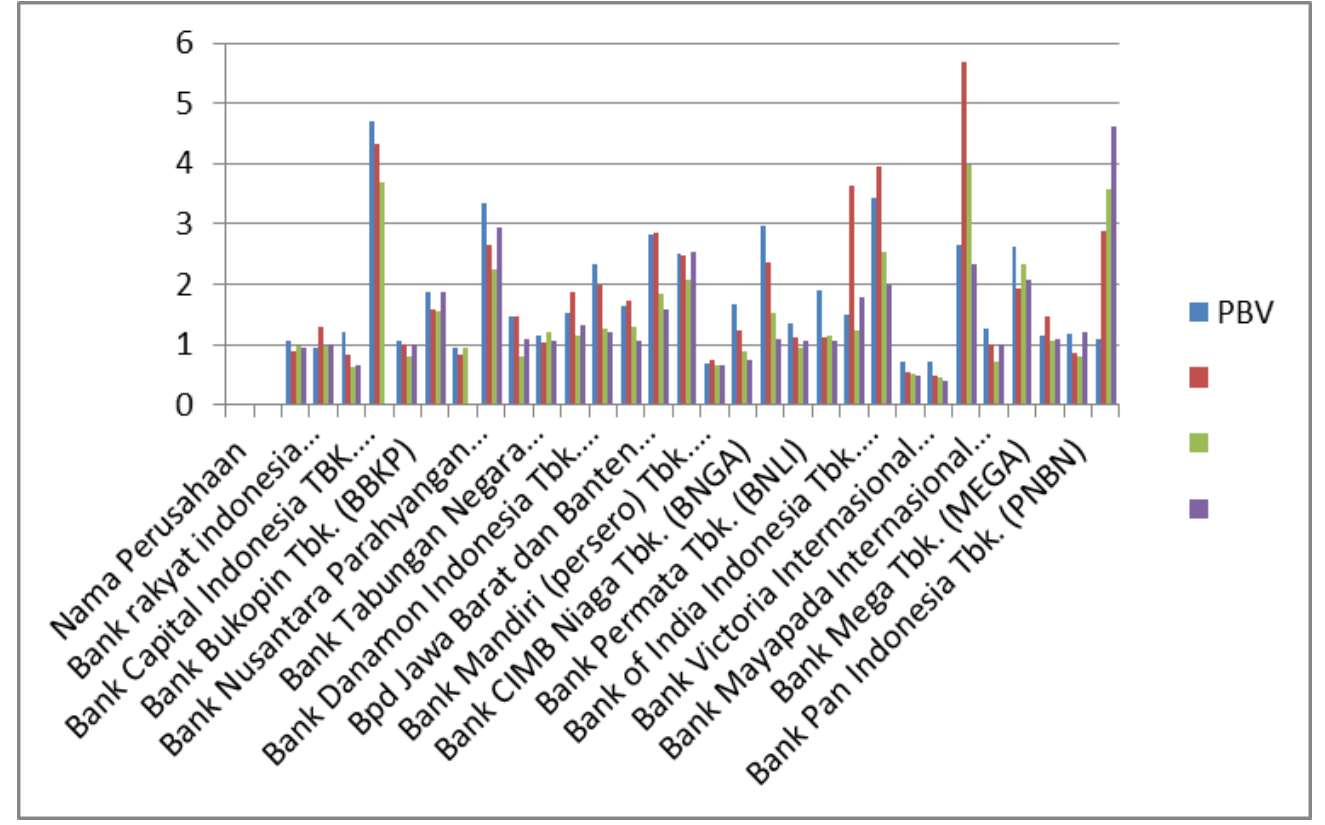

Sumber : data sekunder yang diolah, 2016.

Gambar 1. Daftar nilai PBV Perbankan tahun 2011-2014 
Laba yang berkualitas terbentuk dari laporan keuangan yang benar-benar sesuai fakta. Nilai perusahaan mencerminkan kinerja keuangan perusahaan pada waktu yang lalu dan prospek masa depannya. Dengan kinerja keuangan perusahaan yang baik maka akan maningkatkan kualitas laba. Menurut Susanti (2010) salah satu pengukuran kinerja manajemen adalah besarnya laba yang dihasilkan perusahaan. Informasi laba mempunyai peran sangat penting berguna sebagai pemberi sinyal kinerja keuangan perusahaan guna pembuatan berbagai keputusan yang biasanya digunakan investor untuk berinvestasi di perusahaan. Laba yang tidak menunjukkan informasi sebenarnya tentang kinerja dapat menyesatkan pihak pengguna laporan keuangan.

Salah satu strategi manajemen laba adalah meningkatkan laba yang dilaporkan pada periode kini untuk membuat perusahaan dipandang lebih baik. Cara ini juga memungkinkan peningkatan laba selama beberapa periode. Kualitas laba atau tepatnya kualitas akuntansi memiliki arti berbeda untuk berbagai pihak. Perusahaan dengan kualitas laba tinggi diharapkan memiliki rasio harga terhadap laba (price earning ratio) yang lebih tinggi dibandingkan perusahaan dengan kualitas laba rendah. Definisi lain kualitas laba yaitu perusahaan memiliki laba berkualitas tinggi jika informasi laporan keuangan mencerminkan aktivitas usaha secara akurat (Subramanyam dan Wild, 2014). Artinya laba dapat mencerminkan kinerja keuangan perusahaan dan sebagai bagian dari laporan keuangan dituntut untuk menyajikan laporan keuangan sesuai kondisi ekonomi perusahaan, sehingga dapat dipertanggungjawabkan kualitasnya.

Untuk mewujudkan kinerja keuangan yang baik dan dapat menghasilkan laba yang berkualitas dalam rangka meningkatkan nilai perusahaan dibutuhkan sebuah mekanisme corporate governance. Dalam penerapan good corporate governance terdapat beberapa mekanisme yaitu kepemilikan manajerial, kepemilikan institusional, komisaris independen, dan komite audit. Mekanisme corporate governance ini akan meningkatkan pengawasan bagi perusahaan, sehingga dengan adanya pengawasan diharapkan kinerja perusahaan akan lebih baik. Apalagi pada jaman pasar bebas seperti sekarang ini terlebih pada akhir tahun 2015 negara Indonesia telah memasuki Masyarakat Ekonomi Asean (MEA).

Kegiatan bisnis mulai dituntut mengembangkan dan menerapkan sistem dan paradigma baru dalam pengelolaan bisnis yaitu prinsip-prinsip tata kelola yang baik yaitu good corporate governance (GCG). Good corporate governance adalah suatu pilar dari sistem ekonomi pasar, karena berkaitan dengan kepercayaan publik terhadap perusahaan, sehingga secara eksternal perusahaan akan lebih dipercaya investor. Di Indonesia, good governance mulai banyak diperbincangkan pada pertengahan tahun 1997, yaitu saat krisis ekonomi mulai melanda negara-negara tersebut. Dalam sebuah negara terdapat berbagai macam perusahaan besar dan bisnis lainnya dan semua butuh pengawasan yang biasa disebut dengan GCG. GCG dalam penggunaan di sebuah perusahaan atau bisnis itu sendiri sangat penting untuk mengawasi kegiatan internal dan eksternal perusahaan. Di Indonesia masalah good corporate governance sudah terjadi sejak adanya krisis finansial pada tahun 1997 terutama pada salah satu penyanggah ekonomi Indonesia yaitu sektor perbankan yang mengalami krisis terparah. Salah satu penyebab terjadinya krisis di Indonesia adalah lemahnya pengawasan yang dilakukan terhadap direksi perusahaan yang seharusnya menjadi tanggung jawab dewan komisaris sehiggaa banyak bank yang bangkrut (dilikuidasi). Salah satu penyebab terjadinya kebangkrutan bank tersebut antara lain karena belum diterapkannya mekanisme GCG di lingkungan perbankan. Oleh karena 
itu, pemerintah termasuk Bank Indonesia telah melakukan berbagai upaya untuk mendorong terwujudnya GCG di lingkungan perbankan. Pada tahun 2006 Bank Indonesia mengeluarkan Peraturan Bank Indonesia No. 8/4/PBI/2006 tanggal 30 Januari 2006 tentang pelaksanaan GCG bagi Bank umum. Untuk mengatasi krisis perbankan tersebut, Bank Indonesia dengan API (Arsitektur Perbankan Indonesia ) merumuskan Peraturan Bank Indonesia (PBI) Nomor 8/14/ PBI 2006 agar dapat terciptanya corporate governance, dengan tujuan mengembalikan nama baik perbankan yang sempat terpuruk, menciptakan sistem perbankan yang sehat dan juga melindungi kepentingan para stakeholders. Indonesia adalah negara yang masih rendah menerapkan GCG baik perusahan go public atau tidak, baik sektor keuangan atau lainnya.

Membangun daya saing industri pasar modal tidak hanya sebatas meningkatkan jumlah emiten ataupun nilai transaksi, namun bagaimana membangun budaya transparansi dan akuntabel melalui penerapan prinsip tata kelola perusahaan yang baik atau good corporate governance (GCG). Bicara industri pasar modal sangat erat kaitannya dengan kepercayaan dan tidak hanya sebatas soal angka return atau hasil investasi yang didapatkan. Setidaknya sejuta manfaat yang dirasakan investor terkait penerapan tata kelola perusahaan yang baik, selain peningkatan harga saham dan yang pasti perlindungan dalam berinvestasi. Pasalnya Indonesia mempunyai pengalaman pahit dari buruknya tata kelola perusahaan dengan keterlibatan conflict of intrest para pemegang saham pengendali, sehingga merugikan investor. Kasus Antaboga Sekuritas dan teranyar investasi bodong. Penerapan GCG memang sangat dipengaruhi oleh para pimpinan perusahaan yang diberikan amanah untuk mengelola perusahaan, yaitu Direksi dan Dewan Komisaris, yang kemudian meneruskan itikad tersebut kepada seluruh jajaran perusahaan.
Menyadari betapa pentingnya penerapan tata kelola perusahaan yang baik, sejatinya hal ini sudah menjadi kebutuhan para pelaku industri pasar modal dan tidak hanya pelengkap untuk menaikkan harga saham. GCG menjadi kebutuhan dasar untuk mewujudkan industri keuangan berdaya saing. GCG perlu diterapkan oleh semua pihak termasuk pelaku industri, profesi, konsumen, pemerintah dan regulatorregulator di sektor keuangan.

Data Transparansi Internasional menunjukkan bahwa indeks persepsi korupsi Indonesia pada 2013 berada pada tingkat 114 dari 177 negara. Adapun indeks governance Indonesia berada di level 37 dari maksimal 100 berdasarkan data governance indicator dari World Bank 2014. Ada 5 aspek yang biasa dijadikan pedoman apakah emiten tersebut biasa dikatakan telah menerapkan praktik GCG. Kelima aspek tersebut yakni fungsi dan peran dewan komisaris, hubungan dengan pemegang saham dalam menjamin hak pemegang saham, fungsi dan peran jajaran direksi, partisipasi pihak yang berkepentingan (stakeholders), dan keterbukaan informasi. Diharapkan dengan pedoman GCG, industri pasar modal bisa naik peringkat dari negara tetangga dan memberikan efek jangka panjang bagi investor.

Latar belakang kebutuhan atas GCG, dari latar belakang praktis dapat dilihat dari pengalaman Amerika Serikat yang harus melakukan restrukturisasi corporate governace akibat market crash pada tahun 1929. Darilatarbelakang akademis, kebutuhan GCG timbul berkaitan dengan agency theory dikarenakan perusahaan menginginkan suatu proses pengawasan terhadap keputusan yang dilakukan manajemen agar tidak terjadi penyimpangan. Implementasi dari GCG diharapkan bermanfaat untuk menambah dan memaksimalkan nilai perusahaan (neraca. com). 
Teori keagenan (agency theory) menurut Brigham dan Houston (2010) menyatakan para manajer diberi kekuasaan oleh pemilik perusahaan, yaitu pemegang saham, untuk membuat keputusan, dimana hal ini menciptakan potensi konflik kepentingan yang dikenal sebagai teori keagenan (agency theory). Konflik keagenan yang mengakibatkan adanya sifat opportunistic manajemen akan mengakibatkan rendahnya kualitas laba. Rendahnya kualitas laba akan membuat kesalahan pembuatan keputusan para pemakainya seperti investor dan kreditor, sehingga nilai perusahaan akan berkurang (Siallagan dan Machfoedz, 2006).

Untuk mengungkapkandan mengurangi permasalahan keagenan dengan penerapan good corporate governance yang dapat didefinisikan sebagai tata kelola perusahaan yang baik. Terdapat 4 mekanisme corporate governance yang sering digunakan dalam penelitian mengenai corporate governance yang bertujuan untuk meminimalisir atau mengurangi konflik keagenan, yaitu kepemilikan manajerial, kepemilikan institusional, komisaris independen dan komite audit.

Kepemilikan manajerial merupakan saham perusahaan yang dimiliki oleh manajemen perusahaan (Sari dan Riduwan, 2013). Penelitian Siallagan dan Machfoedz (2006) memperoleh hasil bahwa kepemilikan manajerial berpengaruh positif terhadap kualitas laba sejalan dengan penelitian Sari dan Riduwan (2013). Sementara penelitian Perdana dan Raharja (2014) memperoleh hasil bahwa kepemilikan manajerial berpengaruh positif terhadap nilai perusahaan, sejalan dengan penelitian Muryatri dan Suardikha (2014), namun tidak sejalan dengan penelitian Siallagan dan Machfoedz (2006) karena hasil penelitiannya menyatakan kepemilikan manajerial tidak memiliki pengaruh terhadap nilai perusahaan sehingga hal ini mengindikasikan bahwa semakin tinggi kepemilikan manajerial maka nilai perusahaan akan semakin menurun.
Kepemilikan institusional merupakan saham perusahaan yang dimiliki oleh institusi atau lembaga (perusahaan asuransi, bank, perusahaan investasi dan kepemilikan institusi lain) (Sari dan Riduwan, 2013). Penelitian Sari dan Riduwan (2013) memperoleh hasil bahwa kepemilikan institusional tidak berpengaruh terhadap kualitas laba, sejalan dengan penelitian Lestari dkk (2014) semakin tinggi laba perusahaan, maka deviden yang didapat pemegang saham juga semakin tinggi.

Hasil penelitian positif diperoleh Muryati dan Suardikha (2014), Perdana dan Rahaja (2014) yang memperoleh hasil bahwa kepemilikan institusional berpengaruh positif dan tidak signifikan terhadap nilai perusahaan, namun tidak sejalan dengan penelitian Permanasari (2010) yang menunjukkan bahwa kepemilikan institusional tidak memiliki pengaruh terhadap nilai perusahaan. Kepemilikan institusional yang merupakan pemilik mayoritas cenderung berpihak pada manajemen dan mengarah pada kepentingan pribadi sehingga mengabaikan saham minoritas, hal ini di respon negatif oleh pasar.

Komisaris independen adalah anggota dewan komisaris yang tidak memiliki hubungan keuangan, kepengurusan, kepemilikan saham ataupun hubungan keluarga dengan anggota dewan komisaris lainnya, direksi ataupun pemegang saham pengendali atau hubungan lain yang dapat mempengaruhi kemampuannya untuk bertindak independen (Sari dan Riduwan, 2013). Dalam penelitian Lestari dkk (2014) menunjukkan hasil bahwa komisaris independen berpengaruh terhadap kualitas laba. Hal ini tidak sejalan dengan penelitian Sari dan Riduwan (2013) dan Siallagan dan Machfoedz (2006) yang menyatakan komisaris independen tidak berpengaruh terhadap kualitas laba. Penelitian Muryati dan Suwardikha (2014) memperoleh hasil bahwa dewan komisaris independen berpengaruh positif terhadap nilai perusahaan, dan hal ini 
sama dengan yang diperoleh oleh Perdana dan Raharja (2014).

Komite audit adalah sekelompok orang yang dipilih dari dewan komisaris perusahaan yang bertanggung jawab untuk membantu auditor dalam mempertahankan independensinya dari manajemen. Siallagan dan Machfoedz (2006) dan Lestari dkk (2014) hasil penelitiannya menunjukan bahwa komite audit berpengaruh terhadap kualitas laba, namun perbedaan hasil ditunjukkan dalam penelitian Sari dan Riduwan (2013) yang menyatakan bahwa komite audit tidak berpengaruh terhadap kualitas laba. Siallagan dan Machfoedz (2006) hasil penelitiannya menunjukkan bahwa komite audit berpengaruh positif dan tidak signifikan terhadap nilai perusahaan, namun bertentangan dengan penelitian Muryati dan Suwardikha (2014) yang memperoleh hasil bahwa komite audit independen tidak berpengaruh pada nilai perusahaan, karena peningkatan proporsi komite audit independen justru akan menurunkan nilai perusahaan.

Perbedaan penelitian ini dengan beberapa penelitian di ataas adalah di atas bahwa perbedaan pertama yaitu peneliti ingin menggunakan price book value untuk mengukur nilai perusahaan, perbedaan kedua terletak pada obyek penelitian yaitu peneliti ingin meneliti perusahaan perbankan yang terdaftar di bursa efek, perbedaan ketiga terletak pada periode penelitian 2011-2014. Dengan menggunakan periode penelitian tersebut hasil penelitian lebih mencerminkan keadaan terkini.

Berdasarkan latar belakang yang telah diuraikan sebelumnya, maka dapat diajukan beberapa pertanyaan penelitian, yaitu: a) Apakah mekanisme good corporate governance berpengaruh terhadap kualitas laba pada perusahaan perbankan yang telah terdaftar di bursa efek?, b) Apakah mekanisme good corporate governance berpengaruh terhadap nilai perusahan pada perusahaan perbankan yang telah terdaftar di bursa efek?, c) Apakah kualitas laba berpengaruh terhadap nilai perusahhaan pada perusahaan perbankan yang telah terdaftar di bursa efek?, d) Apakah mekanisme good corporate governance berpengaruh terhadap nilai perusahaan dengan kualitas laba sebagai variabel intervening pada perusahaan perbankan yang telah terdaftar di bursa efek?

Adapun tujuan penelitian ini adalah:

1. Untuk mendapatkan bukti empiris dan menganalisis apakah mekanisme good corporate governance berpengaruh terhadap kualitas laba,

2. Untuk mendapatkan bukti empiris dan menganalisis apakah mekanisme good corporate governance berpengaruh terhadap nilai perusahaan,

3. Untuk mendapatkan bukti empiris dan menganalisis apakah kualitas laba berpengaruh terhadap nilai perusahaan.

\section{TINJAUAN PUSTAKA}

\section{Mekanisme Good Corporate Governance}

Ada empat mekanisme yang dipakai dalam penelitian ini yang bertujuan untuk mengurangi konflik keagenan, yaitu kepemilikan manajerial, kepemilikan institusional, komisaris independent dan komite audit (Sari dan Riduwan, 2013):

\section{a. Kepemilikan Manajerial}

Kepemilikan manajerial atau kepemilikan saham manajemen adalah kepemilikan saham perusahaan yang dimiliki oleh manajemen baik direksi, komisaris maupun karyawan dengan persyaratan tertentu untuk memiliki saham perusahaan. Menurut Perdana dan Raharja (2014) kepemilikan manajerial akan mendorong manajemen untuk meningkatkan kinerja perusahaan, karena mereka juga memiliki perusahaan. 
b. Kepemilikan Institusional

Kepemilikan institusional merupakan saham perusahaan yang dimiliki oleh institusi atau lembaga (perusahaan asuransi, bank, perusahaan investasi, dan kepemilikan institusi lain). Investor institusi sering disebut investor canggih (sophisticated) sehingga seharusnya lebih dapat menggunakan informasi periode sekarang dalam memprediksi laba masa depan dibanding investor institusional.

\section{c. Komisaris Independen}

Komisaris independen adalah anggota dewan komisaris yang tidak memiliki hubungan keuangan, kepengurusan, kepemilikan saham ataupun hubungan keluarga dengan anggota dewan komisaris lainnya, direksi ataupun pemegang saham pengendali atau hubungan lain yang dapat mempengaruhi kemampuanya untuk bertindak independen. Keberadaan komisaris independen dimaksudkan untuk mendorong terciptanya iklim dan lingkungan kerja yang lebih obyektif dan menempatkan kewajaran dan kesetaraan di antara berbagai kepentingan termasuk kepentingan pemegang saham minoritas dan stakeholders lainnya.

d. Komite Audit

Komite audit adalah dalam rangka penyelenggaraan pengelolaan perusahaan yang baik (good corporate governance), Bursa Efek Indonesia (BEI) dan Badan Pengawas Pasar Modal (BAPEPAM) mewajibkan perusahaan publik untuk memiliki komite audit. Komite audit bertugas untuk memberikan pendapat profesional yang independen kepada dewan komisaris terhadap laporan atau hal-hal yang disampaikan oleh direksi dewan komisaris serta mengidentifikasikan hal-hal yang memerlukan perhatian dewan komisaris.

\section{Kualitas Laba}

Laba adalah merupakan informasi utama yang disajikan dalam laporan keuangan, sehingga angka-angka dalam laporan keuangan, menjadi hal krusial yang mesti harus dicermati oleh pemakai laporan keuangan. Hal ini karena angka-angka dalam laporan keuangan merupakan fungsi dari kebijakan dan metode-metode akuntansi yang dipilih oleh perusahaan (Sari dan Riduwan, 2013).

\section{Nilai Perusahaan}

Nilai perusahaan merupakan harga jual perusahaan yang dianggap layak oleh calon investor sehingga ia mau membayarnya jika suatu perusahaan akan dijual. Bagi perusahaan yang menjual sahamnya ke masyarakat (go public), indikator nilai perusahaan adalah harga saham yang diperjualbelikan di bursa efek. Pendapat ini didasarkan atas pemikiran bahwa peningkatan harga saham identik dengan peningkatan kemakmuran para pemegang saham, dan peningkatan harga saham identik dengan peningkatan nilai perusahaan. Meskipun demikian, tidak berarti bahwa nilai perusahaan sama dengan harga saham (Fuad dkk, 2006).

\section{Leverage}

Leverage akan menggambarkan sejauh mana aset perusahaan dibiayai oleh hutang dibandingkan dengan modal sendiri. Leverage juga merupakan penaksir dari risiko yang melekat pada suatu perusahaan. Sebaiknya perusahaan mengusahakan sumber pendanaan dari internal terlebih dahulu dari pada menggunakan sumber pendanaan eksternal. Dengan demikian, rasio leverage yang tinggi menyebabkan turunya nilai perusahaan. Variabel kontrol yang digunakan dalam penelitian ini adalah leverage yang merupakan total utang dibagi dengan total asset. Variabel ini digunakan sebagai variabel kontrol karena terbukti dapat mengurangi konflik kepentingan antara manajer dengan 
pemberi pinjaman (bondholders) (Siallagan dan Machfoedz, 2006).

\section{Hipotesis}

\section{Pengaruh Kepemilikan Manajerial terhadap Kualitas Laba}

Gabrielsen et. al. (2002) menguji hubungan antara kepemilikan manajerial dan kandungan informasi laba serta discretionary accrual. Dengan menggunakan data pasar modal Denmark ditemukan adanya hubungan yang positif tetapi tidak signifikan antara kepemilikan manajerial dan discretionary accrual dan hubungan negatif antara kepemilikan manajerial dan kandungan informasi laba. Siallagan dan Machfoedz (2006) menemukan bukti bahwa kepemilikan manajerial mempengaruhi kualitas laba, semakin besar kepemilikan manajerial maka discretionary accrual semakin rendah. Hal ini sesuai dengan teori yang menyatakan bahwa semakin besar kepemilikan manajemen dalam perusahaan maka manajemen akan cenderung berusaha untuk meningkatkan kinerjanya. Penelitian Lestari dkk (2014) menunjukkan bahwa kepemilikan manajerial memberikan pengaruh positifterhadap kualitas laba, dengan adanya kepemilikan saham oleh manajemen juga dapat menyelaraskan pandangan antara manajemen dan pemegang saham lain, sehingga masalah keagenan diasumsikan akan hilang. Selain itu kepemilikan manajerial, maka manajemen mempunyai rasa memiliki perusahaan, sehingga meminimalkan terjadinya manajemen laba yang dapat menurunkan kualitas laba karena manajemen yang juga merupakan pemilik perusahaan mempunyai rasa ingin tahu terhadap kondisi perusahaan yang sebenarnya. Hipotesis dalam penelitian ini adalah:

$\mathrm{H}_{1}$ : Kepemilikan manajerial berpengaruhpositif dan signifikan terhadap kualitas laba.

\section{Pengaruh Kepemilikan Institusional terhadap Kualitas Laba}

Kepemilikan mewakili suatu sumber kekuasaan (source of power) yang dapat digunakan untuk mendukung atau sebaliknya terhadap keberadaan manajemen. Investor institusional sering disebut juga sebagai investor canggih (shopisticated) dan seharusnya lebih dapat menggunakan informasi periode sekarang di dalam memprediksi laba masa depan (Siregar dan Utama, 2006). Boediono (2005) mengungkapkan bahwa kepemilikan institusional berpengaruh positif terhadap kualitas laba, yang berarti bahwa semakin tinggi kepemilikan institusional maka laba yang dihasilkan semakin berkualitas. Dalam kaitannya dengan fungsi monitoring dalam perusahaan, keberadaan investor institusional memiliki kemampuan yang lebih baik dari pada investor individual, investor institusional diyakini mampu memonitor tindakan para manajer lebih baik dibanding investor individual. Investor institusional juga sebagai monitoring agent. Kepemilikan institusional dapat menjadi kendala bagi perilaku oportunistik manajer yang memanfaatkan management discreation untuk kepentingan pribadinya yang kemungkinan dapat merugikan pihak lain. Dengan adanya tingkat kepemilikan institusional yang tinggi akan menyebabkan pengawasan yang lebih besar dan lebih efektif. Keberadaan investor institusional mampu memonitor kinerja manajemen dengan lebih baik sehingga tindakan manajemen laba dapat dikurangi dan akan meningkatkan kualitas laba yang dilaporkan (Susanti, 2010). Hipotesis dalam penelitian ini adalah:

$\mathrm{H}_{2}$ : Kepemilikan institusional berpengaruh positif dan signifikan terhadap kualitas laba.

\section{Pengaruh Dewan Komisaris Inde- penden terhadap Kualitas Laba}

Dewan komisaris sebagai puncak dari sistem pengelolaan internal perusahaan, 
memiliki peranan terhadap aktivitas pengawasan. Vafeas (2000) mengatakan bahwa selain kepemilikan manajerial, peranan dewan komisaris juga diharapkan dapat meningkatkan kualitas laba dengan membatasi tingkat manajemen laba melalui fungsi monitoring atas pelaporan keuangan. Fungsi monitoring yang dilakukan oleh dewan komisaris dipengaruhi oleh jumlah atau ukuran dewan komisaris. Komisaris independen melalui perannya dalam menjalankan fungsi pengawasan dapat mempengaruhi pihak manajemen dalam menyusun laporan keuangan sehingga dapat diperoleh suatu laporan laba yang sebenarnya. Hasil analisis menunjukkan besarnya pengaruh langsung dewan komisaris terhadap kualitas laba sebesar 5,29\% dan mempunyai hubungan yang positif. Akan tetapi jika dilihat kuatnya pengaruh mekanisme ini terhadap kualitas laba dapat dikatakan sangat lemah (Boediono, 2005). Lestari dkk (2014) dalam penelitiannya membuktikan bahwa dewan komisaris berpengaruh terhadap kualitas laba. Keberadaan komisaris independen dalam sebuah perusahaan dapat menekan manajemen untuk tidak melakukan manipulasi terhadap laba yang nantinya akan menurunkan kualitas laba. Komisaris independen dianggap dapat melakukan pengawasan yang efektif terhadap kinerja manajemen. Selain itu, sifat independensi yang dimiliki menjadikan komisaris independen tidak mudah percaya terhadap laporan yang dibuat manajemen. Hipotesis dalam penelitian ini adalah:

$\mathrm{H}_{3}$ : Komisaris independen berpengaruh positif dan signifikan terhadap kualitas laba.

\section{Pengaruh Keberadaan Komite Audit terhadap Kualitas Laba}

Klein (2002) memberikan bukti secara empiris bahwa perusahaan yang membentuk komite audit independen melaporkan laba dengan kandungan akrual diskresioner yang lebih kecil dibandingkan dengan perusahaan yang tidak membentuk komite audit independen. Kandungan dicretionary accruals tersebut berkaitan dengan kualitas laba perusahaan. Penelitian Siallagan dan Machfoedz (2006) menunjukkan bahwa komite audit berpengaruh positif terhadap kualitas laba. Memberikan bukti bahwa perusahaan yang membentuk komite audit independen melaporkan laba dengan kandungan akrual diskresioner yang lebih kecil dibandingkan dengan perusahaan yang tidak membentuk komite audit independen. Keberadaan komite audit dalam pengelolaan perusahaan sangat penting karena komite audit sebagai penghubung antara pemegang saham dan dewan komisaris. Penelitian Susanti (2010) menunjukkan bahwa komite audit beerpengaruh terhadap kualitas laba. Hipotesis dalam penelitian ini adalah:

$\mathrm{H}_{4}$ : Komite audit berpengaruh positif dan signifikan terhadap kualitas laba.

\section{Pengaruh Kualitas Laba terhadap Nilai Perusahaan.}

Kualitas laba yang rendah dapat membuat kesalahan pembuatan keputusan para pemakainya seperti investor dan kreditor, sehingga nilai perusahaan akan berkurang. Kondisi ini biasanya terjadi karena informasi yang digunakan dalam membuat keputusan bukanlah informasi yang sebenarnya. Discretionry accrual memiliki hubungan yang negatif dengan nilai perusahaan, dengan demikian hipotesis yang menyatakan kualitas laba secara positif berpengaruh terhadap nilai perusahaan didukung (Siallagan dan Machfoedz, 2006). Dengan laporan keuangan yang sebenarnya akan mempengaruhi kualitas laba. Lestari dkk (2014) mengungkapkan bahwa kualitas laba terhadap nilai perusahaan berpengaruh positif. Semakin berkualitas laba yang dilaporkan, maka akan meminimalkan kesalahan pembuatan keputusan para pemakai laporan keuangan, sehingga nilai perusahaan tetap terjaga. Laba yang 
berkualitas juga dapat menjelaskan nilai pasar perusahaan yang sebenarnya karena bagi perusahaan yang menerbitkan saham dipasar modal harga saham yang ditransaksikan di bursa merupakan indikator nilai perusahaan. Hipotesis dalam penelitian ini adalah:

$\mathrm{H}_{5}$ : Kualitas laba berpengaruh positif dan signifikan terhadap nilai perusahaan.

\section{Pengaruh Kepemilikan Manajerial terhadap Nilai Perusahaan}

Struktur kepemilikan (kepemilikan manajerial dan kepemilikan institusional) oleh beberapa peneliti dipercaya mampu mempengaruhi jalannya perusahaan yang pada akhirnya berpengaruh pada kinerja perusahaan dalam mencapai tujuan perusahaan yaitu maksimilisasi nilai perusahaan. Siallagan dan Machfoedz (2006) menyatakan Good Corporate Governance merupakan suatu sistem yang mengatur dan mengendalikan perusahaan yang diharapkan dapat memberikan dan meningkatkan nilai perusahaan kepada para pemegang saham. Dengan demikian, penerapan good corporate governance dipercaya dapat meningkatkan nilai perusahaan. Penelitian Perdana dan Raharja (2014) menunjukkan bahwa corporate governance secara positif berpengaruh terhadap nilai perusahaan. Kepemilikan manajerial, kepemilikan institusional, komisaris independen berpengaruh positif terhadap nilai perusahaan (Muryati dan Suardikha, 2014). Menurut Sujoko dan Soebiantoro (2007) kepemilikan manajerial akan mendorong manajemen untuk meningkatkan kinerja perusahaan, karena mereka juga memiliki perusahaan. Kinerja perusahaan yang meningkat akan meningkatkan nilai perusahaan. Sejalan dengan penelitian Perdana dan Raharja (2014) dan Muryati dan Suardikha (2014) yang mengungkapkan bahwa kepemilikan manajerial berpengaruh positif terhadap nilai perusahaan. Hipotesis dalam penelitian ini adalah:
$\mathrm{H}_{6}$ : Kepemilikan manajerial berpengaruh positif dan signifikan terhadap nilai perusahaan.

\section{Pengaruh Kepemilikan Institusional terhadap Nilai Perusahaan}

Investor institusional dapat berperan dalam memonitor agen (manajer) perusahaan. Selain itu, investor institusional memiliki akses informasi yang lebih baik karena aktivitas investasi mereka, yang berarti pengetahuan yang lebih baik tentang kinerja perusahaan yang akan berpengaruh terhadap nilai perusahaan (Ellili, 2011). Dengan adanya kepemilikan institusional dalam suatu perusahaan akan berpengaruh terhadap nilai perusahaan dengan kemampuannya yang bertugas untuk mengawasi manajer dengan jumlah presentase saham atau hak suara yang dimiliki oleh institusi. Muryati dan Suardikha (2014) mengemukakan tingginya kepemilikan institusional akan memberikan pengaruh pada proses laporan keuangan, sehingga dapat memberikan reaksi positif pada calon investor dalam menilai perusahaan. Dengan pengawasan yang dilakukan institusional kepada manajemen maka laporan keuangan perusahaan sesuai keadaan perusahaan yang sebenarnya tanpa adanya kecurangan. Tugas institusi yang selalu mengawasi juga mampu mengurangi biaya keagenan dengan begitu nilai perusahaan juga akan meningkat. Perdana dan Raharja (2014) mengungkapkan bahwa kepemilikan institusional berpengaruh positif terhadap nilai perusahaan sejalan dengan Muryati dan Suardikha (2014). Hipotesis dalam penelitian ini adalah:

$\mathrm{H}_{7}$ : Kepemilikan institusional berpengaruh positif dan signifikan terhadap nilai perusahaan.

\section{Pengaruh Dewan Komisaris Independen terhadap Nilai Perusa- haan}

Adanya komisaris independen diharapkan mampu meningkatkan peran 
dewan komisaris sehingga tercipta good corporate governance di dalam perusahaan (Perdana dan Raharja, 2014). Manfaat corporate governance akan dilihat dari harga premium yang bersedia dibayar oleh investor atas ekuitas perusahaan (harga pasar). Jika ternyata investor bersedia lebih mahal, maka nilai pasar perusahaan yang menerapkan good corporate governance juga akan lebih tinggi dibanding perusahaan yang tidak menerapkan atau mengungkapkan praktek good corporate governance (Rachmawati dan Triatmoko, 2007). Komisaris independen memiliki pengaruh terhadap kinerja manajemen agar lebih memaksimalkan kinerjanya dengan pengawasan yang lebih efektif. Komisaris independen juga menjadi penengah antara manajemen dengan pemegang saham sehingga konflik keagenan yang bisa menurunkan nilai perusahaan bisa diatasi. Independensi yang dimiliki membuat komisaris independen tidak mudah dipengaruhi oleh hubungan bisnis atau hubungan lain yang dapat mempengaruhi kemampuannya dalam membuat keputusan guna kepentingan perusahaan (Lestari dkk, 2014). Perdana dan Raharja (2014) menyatakan bahwa dewan komisaris berpengaruh positifterhadapnilai perusahaan, hasil ini sejalan dengan penelitian Lestari dkk (2014) dan Siallagan dan Machfoedz (2006). Hipotesis dalam penelitian ini adalah:

$\mathrm{H}_{8}$ : Dewan komisaris independen berpengaruh positif dan signifikan terhadap nilai perusahaan.

\section{Pengaruh Komite Audit terhadap Nilai Perusahaan}

Komite audit mempunyai peranan yang sangat penting dan strategis dalam hal memelihara kredibilitas proses penyusunan laporan keuangan seperti halnya menjaga terciptanya sistem pengawasan perusahaan yang memadai serta dilaksanakannya good corporate governance. Investor menilai suatu perusahaan dengan cara membaca informasi yang disajikan dalam laporan keuangan, dengan kualitas laporan keuangan yang baik maka akan meningkatkan nilai perusahaan (Susanti, 2010). Adanya komite audit yang bertanggung jawab atas kredibilitas dan kualitas laporan keuangan perusahaan yang nantinya laporan keuangan tersebut akan digunakan oleh pihak internal dan eksternal perusahaan jelas akan berpengaruh terhadap nilai perusahaan (Purbopangestu dan Subowo, 2014). Siallagan dan Machfoedz (2006) mengungkapkan bahwa komite audit berpengaruh positif terhadap nilai perusahaan. Hipotesis dalam penelitian ini adalah:

$\mathrm{H}_{9}$ : Keberadaan komite audit berpengaruh positif dan signifikan terhadap nilai perusahaan.

\section{Kualitas Laba sebagai Variabel In- tervening}

Menurut Siallagan dan Machfoedz (2006), kualitas laba bukan variabel intervening pada hubungan antara corporate governance dan nilai perusahaan, sejalan dengan penelitian Sari dan Riduwan (2013). Oleh karena nilai koefisien beta variabel independen mengalami kenaikan, sedangkan persyaratan untuk memunculkan variabel intervening adalah dengan adanya penurunan nilai koefisien beta variabel independen baik signifikan ataupun tidak. Kualitas laba hanya menjadi mediator pengaruh kepemilikan manajerial terhadap nilai perusahaan (Lestari dkk, 2014). Siallagan dan Machfoedz (2006) mengungkapkan bahwa leverage berpengaruh positif secara signifikan terhadap nilai perusahaan. Hipotesis dalam penelitian ini adalah:

$\mathrm{H}_{10}$ : Kualitas laba mempunyai pengaruh mediasi pada hubungan antara corporate governance dan nilai perusahaan.

\section{METODE PENELITIAN}

Populasi dalam penelitian ini adalah perusahaan perbankan yang terdaftar di 
Bursa Efek Indonesia pada tahun 20112014. Penggunaan tahun 2011-2014 sebagai periode dalam penentuan populasi dan sampel adalah untuk melihat konsistensi pengaruh masing-masing variabel independen terhadap variabel dependen. Selain itu, pemilihan sampel laporan tahunan yang diterbitkan oleh perusahaan perbankan tahun 2011-2014.

Teknik pengambilan sampel dalam penelitian ini menggunakan teknik purposive sampling. Kriteria yang digunakan untuk memilih sampel adalah sebagai berikut (Sari dan Riduwan, 2013):

a. Perusahaan perbankan yang sudah terdaftar di Bursa Efek Indonesia selama periode 2011-2014.

b. Perusahaan yang mempublikasikan laporan keuangan tahunan selama berturut-turut untuk periode 31 Desember 2011-2014 yang dinyatakan dalam rupiah.

c. Data perusahaan tersedia lengkap mengenai kepemilikan manajerial, kepemilikan institusional, komisaris independen, komite audit.

Berdasarkan pada kriteria pengambilan sampel yang telah dijelaskan di atas, maka jumlah perusahaan perbankan yang dijadikan sampel sesuai dengan kriteria penelitian adalah 28 perusahaan perbankan selama periode tahun 2011-2014. Analisis statistik deskriptif digunakan untuk melihat kenderungan dari masing-masing variabel penelitian. Tabel 2 menyajikan ringkasan statistik deskriptif dari masing-masing variabel.

Deskripsi mengenai kepemilikan saham oleh institusi (INST) menunjukkan rata-rata sebesar 0,7910 atau $79,10 \%$. Hal ini berarti bahwa rata-rata saham dari perusahaan sampel selama tahun 2011-2014 diperoleh bahwa $79,10 \%$ sahamnya dimiliki oleh institusi atau organisasi lain (perusahaan atau institusi lain). Nilai terendah dari kepemilikan saham institusi adalah sebesar 0,3810 atau $38,10 \%$ dan nilai kepemilikana saham institusi tertinggi adalah 0,9580 atau $95,80 \%$. Tingginya kepemilikan saham institusi dapat berfungsi sebagai pengontrol manajemen.

Deskripsi kepemilikan saham oleh manajerial (MANJ) menunjukkan rata-rata sebesar 0,0654 atau $6,54 \%$. Hal ini berarti bahwa rata-rata saham dari perusahaan sampel selama tahun 2011-2014, diperoleh bahwa $6,54 \%$ sahamnya dimiliki oleh manajerial (anggota dewan komisaris maupun dewan direksi). Jumlah kepemilikan saham manajerial yang paling rendah adalah sebesar $0,00 \%$ dan nilai tertinggi adalah 0,520 atau 45,20\%. Kepemilikan saham oleh manajerial menunjukkan kepentingan ganda dari manajer yaitu sebagai agent sekaligus sebagai principal. Dalam hal ini diharapkan manajer yang memiliki saham dapat mewakili kepentingan pemegang saham lainnya.

Tabel 2 Deskripsi Variabel Penelitian

\begin{tabular}{lccccc}
\hline \multicolumn{1}{c}{ Variable } & N & Minimum & Maxsimum & Mean & Std. Dev. \\
\hline INST & 112 & 0.3810 & 0.9580 & 0.7910 & 0.1046 \\
\hline MANJ & 112 & 0.0000 & 0.3520 & 0.06554 & 0.0722 \\
\hline KOMIND & 112 & 0.1110 & 0.9000 & 0.5893 & 0.1735 \\
\hline KA & 112 & 3.0000 & 8.0000 & 4.2321 & 1.1623 \\
\hline LEV & 112 & 0.1050 & 7.8480 & 0.9019 & 0.9868 \\
\hline KL & 112 & -0.2413 & 0.2878 & 0.0039 & 0.0765 \\
\hline PBV & 112 & 0.3800 & 5.7000 & 1.6963 & 1.0719 \\
\hline Valid N (listwise) & 112 & & & & \\
\hline
\end{tabular}

Sumber : Data sekunder diolah, 2016. 
Deskripsi dewan komisaris independen (KOMIND) dari perusahaan sampel diperoleh sebesar 0,5893 atau 58,93\%. Hal ini ini berarti bahwa jumlah komisaris independen dari perusahaan sampel rata-rata sebesar 58,93\% dari seluruh jumlah dewan komisaris. Kondisi demikian menunjukkan bahwa secara rata-rata perusahaanperusahaan sampel telah memenuhi syarat minimal $30 \%$ anggota dewan komisaris independen. Jumlah terendah adalah sebesar 0,1110 atau $11,10 \%$ dan jumlah tertinggi mendapai 0,9000 atau $90,0 \%$.

Deskripsi variabel leverage yang diukur dengan debt to asset ratio menunjukkan ratarata sebesar 0,9019. Hal ini berarti bahwa perusahaan sampel rata-rata memiliki total hutang sebesar 0,9019 atau 90,10\% dari total aset yang dimiliki perusahaan sampel. Nilai LEV tertinggi adalah sebesar 7,8480 sedangkan nilai LEV terendah adalah sebesar 0,1050 .

Estimasi kualitas laba yang diukur dengan negatif discretionary acrual (DA) dengan estimasi model modified Jones diperoleh rata-rata discretionary accrual sebesar 0,0039. Nilai minimum kualitas audit adalah sebesar -0,24134 yang menunjukkan kecilnya tindakan menurunkan laba, sedangkan nilai kualitas audit tertinggi adalah sebesar 0,2878 yang menunjukkan adanya manajemen laba dari selisih aktual estimasi akrual yang seharusnya diperoleh perusahaan.

Nilai perusahaan yang diukur dengan menggunakan PBV menunjukkan rata-rata sebesar 1,8963. PBV yang berada di atas 1 menunjukkan bahwa perusahaan secara rata-rata mengalami pertumbuhan nilai perusahaan. Nilai terendah dari PBV adalah sebesar 0,38 dan nilai tertinggi adalah 5,70.

\section{HASIL DAN PEMBAHASAN}

\section{Pengujian Hipotesis 1,2,3, dan 4}

Persamaan regresi 1 digunakan untuk menjawab hipotesis $1,2,3$, dan 4 serta untuk mengetahui apakah varibel kontrol berpengaruh terhadap kualitas laba.

Tabel 3. Uji t Model Regresi - 1

\begin{tabular}{lccccc}
\hline Model & \multicolumn{2}{c}{$\begin{array}{c}\text { Unstand. } \\
\text { Coeffi. }\end{array}$} & $\begin{array}{c}\text { Stand. } \\
\text { Coeff }\end{array}$ & T & Sig \\
\hline \multicolumn{7}{c}{ B } & $\begin{array}{c}\text { Std. } \\
\text { Error }\end{array}$ & Beta & & \\
& & & & \\
\hline (Constant) & -.150 & .060 & & -2.498 & .014 \\
INST & .028 & .069 & .038 & .405 & .686 \\
MANJ & .138 & .104 & .130 & 1.324 & .188 \\
K O - & .115 & .040 & .261 & 2.857 & .005 \\
MIND & & & & & \\
KL & .015 & .006 & .223 & 2.389 & .019 \\
LEV & -.008 & .007 & -.099 & -1.137 & .258 \\
\hline
\end{tabular}

Dependent Variable: KL

Sumber: Data sekunder diolah, 2016

Persamaan regresi dapat ditulis sebagai berikut:

$\mathrm{KL}=-0,150+0,028 \mathrm{INST}+0,138 \mathrm{MANJ}+$ 0,115 KOMIND + 0,022 15-0,008 LEV + e

Pengujian secara parsial atau individual terhadap pengaruh masing-masing variabel diperoleh sebagai berikut:

\section{Variabel Kepemilikan Manajerial} terhadap Kualitas Laba

Pengujian hipotesis mengenai pengaruh variabel kepemilikan saham manajerial terhadap kualiats laba menunjukkan nilai $\mathrm{t}$ sebesar 1,324 dengan signifikansi sebesar 0,188 . Nilai signifikansi tersebut lebih besar dari 0,05. Hal ini berarti bahwa kepemilikan saham manajerial tidak memiliki pengaruh yang signifikan terhadap kualitas laba. Dengan demikian Hipotesis 1 ditolak.

2. Variabel Kepemilikan Institusional terhadap Kualitas Laba

Pengujian hipotesis mengenai pengaruh variabel kepemilikan saham institusional terhadap kualitas laba menunjukkan nilai $\mathrm{t}$ sebesar 0,405 dengan signifikansi sebesar 0,685 . Nilai signifikansi tersebut lebih besar dari 0,05. Hal ini berarti bahwa kepemilikan saham institusi tidak memiliki pengaruh yang signifikan terhadap kualitas laba. Dengan 
demikian Hipotesis 2 ditolak.

3. Variabel Proporsi Dewan Komisaris Independen terhadap Kualitas Laba

Pengujian hipotesis mengenai pengaruh variabel proporsi dewan komisaris independen terhadap kualitas laba menunjukkan nilai $\mathrm{t}$ sebesar 2,757 dengan signifikansi sebesar 0,005 . Nilai signifikansi tersebut lebih kecil dari 0,05 . Hal ini berarti bahwa proporsi dewan komisaris independen memiliki pengaruh positif yang signifikan terhadap kualitas laba. Dengan demikian Hipotesis 3 diterima.

4. Variabel Komite Audit terhadap Kualitas laba

Pengujian hipotesis mengenai pengaruh variabel komite audit independen terhadap kualitas laba menunjukkan nilai $\mathrm{t}$ sebesar 2,389 dengan signifikansi sebesar 0,019. Nilai signifikansi tersebut lebih kecil dari 0,05. Hal ini berarti bahwa komite audit independen memiliki pengaruh positif yang signifikan terhadap kualitas laba. Dengan demikian Hipotesis 4 diterima.

5. Variabel Kontrol Leverage terhadap Kualitas laba

Pengujian mengenai pengaruh variabel kontrol leverage terhadap kualiatas laba menunjukkan nilai t sebesar -1,137 dengan signifikansi sebesar 0,258 . Nilai signifikansi tersebut lebih besar dari 0,05. Hal ini berarti bahwa leverage tidak memiliki pengaruh yang signifikan terhadap kualitas laba.

\section{Pengujian Hipotesis 5,6,7,8, dan 9}

Persamaan regresi 2 digunakan untuk menjawab hipotesis 5,6,7,8 dan 9 serta untuk mengetahui apakah varibel kontrol berpengaruh terhadap kualitas laba

Tabel 4. Uji t Model Regresi - 2

\begin{tabular}{ccccc}
\hline $\begin{array}{c}\text { MOD- } \\
\text { EL }\end{array}$ & $\begin{array}{c}\text { Unstandardized } \\
\text { Coefficients }\end{array}$ & $\begin{array}{c}\text { Stand. } \\
\text { Coeff }\end{array}$ & t & Sig \\
\hline & B & $\begin{array}{c}\text { Std. } \\
\text { Error }\end{array}$ & Beta & \\
\hline
\end{tabular}

\begin{tabular}{llllll}
\hline (Const.) & -.447 & .434 & & -1.030 & .305 \\
INST & .058 & .486 & .010 & .119 & .906 \\
MANJ & 3.202 & .733 & .393 & 4.366 & .000 \\
K O - & .627 & .293 & .185 & 2.139 & .035 \\
MIND & & & & & \\
KA & .044 & .044 & .087 & 1.003 & .318 \\
LEV & -.018 & .047 & -.031 & -.385 & .701 \\
KL & 1.429 & .680 & .186 & 2.102 & .038 \\
\hline
\end{tabular}

a. Dependent Variable: LnPBV

Sumber: Data sekunder diolah, 2016.

Persamaan regresi dapat ditulis sebagai berikut :

LnPBV $=-0,447+0,058$ INST $+3,202$ MANJ + 0,627 KOMIND + 0,044 KA $0,018 \mathrm{LEV}+1,429 \mathrm{KL}+\mathrm{e}$

Hasil pengujian adalah sebagai berikut:

1. Variabel Kualtas Laba terhadap Nilai Perusahaan

Pengujian hipotesis mengenai pengaruh variabel kualitas laba terhadap nilai perusahaan menunjukkan nilai t sebesar 2,102 dengan signifikansi sebesar 0,038. Nilai signifikansi tersebut lebih kecil dari 0,05 . Hal ini berarti bahwa kualitas laba memiliki pengaruh yang signifikan terhadap nilai perusahaan. Dengan demikian Hipotesis 5 diterima.

2. Variabel Kepemilikan Manajerial terhadap Nilai Perusahaan

Pengujian hipotesis mengenai pengaruh variabel kepemilikan saham manajerial terhadap nilai perusahaan menunjukkan nilai t sebesar 4,366 dengan signifikansi sebesar 0,000 . Nilai signifikansi tersebut lebih kecil dari 0,05. Hal ini berarti bahwa kepemilikan saham manajerial memiliki pengaruh yang signifikan terhadap nilai perusahaan. Dengan demikian Hipotesis 6 diterima.

3. Variabel Kepemilikan Institusional terhadap Nilai Perusahaan

Pengujian hipotesis mengenai pengaruh variabel kepemilikan institusional terhadap nilai perusahaan menunjukkan nilai 
t sebesar 0,119 dengan signifikansi sebesar 0,906. Nilai signifikansi tersebut lebih besar dari 0,05. Hal ini berarti bahwa kepemilikan institusional tidak memiliki pengaruh yang signifikan terhadap nilai perusahaan. Dengan demikian Hipotesis 7 ditolak.

4. Variabel Proporsi Dewan Komisaris Independen terhadap Nilai Perusahaan

Pengujian hipotesis mengenai pengaruh variabel proporsi dewan komisaris independen terhadap nilai perusahaan menunjukkan nilai t sebesar 2,199 dengan signifikansi sebesar 0,035 . Nilai signifikansi tersebut lebih kecil dari 0,05 . Hal ini berarti bahwa proporsi dewan komisaris independen memiliki pengaruh positif yang signifikan terhadap nilai perusahaan. Dengan demikian Hipotesis 8 diterima.

5. Variabel Komite Audit terhadap Nilai Perusahaan

Pengujian hipotesis mengenai pengaruh variabel komite audit terhadap nilai perusahaan menunjukkan nilai t sebesar 1,003 dengan signifikansi sebesar 0,318. Nilai signifikansi tersebut lebih besar dari 0,05 . Hal ini berarti bahwa komite audit tidak memiliki pengaruh yang signifikan terhadap nilai perusahaan. Dengan demikian Hipotesis 9 ditolak.

6. Variabel Kontrol Leverage terhadap Nilai Perusahaan

Pengujian mengenai pengaruh variabel kontrol leverage terhadap nilai perusahaan menunjukkan nilai t sebesar -0,385 dengan signifikansi sebesar 0,701. Nilai signifikansi tersebut lebih besar dari 0,05. Hal ini berarti bahwa variabel kontrol leverage tidak memiliki pengaruh yang signifikan terhadap nilai perusahaan.

\section{Pengaruh Tidak Langsung}

Pengujian hipotesis mengenai pengaruh tidak langsung dari GCG terhadap nilai perusahaan PBV melalui kualitas laba menunjukkan bahwa mekanisme GCG komisaris independen dan komite audit berpengaruh sigifikan terhadap kualitas laba, sedangkan kualitas laba memiliki pengaruh signifikan tehadap nilai perusahaan PBV. Dengan demikian kualitas laba merupakan variabel intervening pada pengaruh GCG terhadap nilai perusahaan. Dengan demikian Hipotesis 10 diterima.

\section{Pengaruh kepemilikan manajerial terhadap kualitas laba}

Jumlah kepemilikan manjerial menunjukkan tidak berpengaruh signifikan terhadap kualitas laba. Hasil ini menjelaskan bahwa kepemilikan saham oleh manajerial yang dimilikitidakakanmemperbesarpeluang perusahaan dalam melaporkan manajemen laba dan cenderung meningkatkan asimetri informasi kepada para pemegang saham. Dari sudut pandang teori akuntansi, manajemen laba sangat ditentukan oleh motivasi manajer perusahaan. Motivasi yang berbeda akan menghasilkan besaran manajemen laba yang berbeda, seperti antara manajer yang juga sekaligus sebagai pemegang saham dan manajer yang tidak sebagai pemegang saham. Dua kriteria ini akan mempengaruhi manajemen laba, sebab kepemilikan seorang manajer akan ikut menentukan kebijakan dan pengambilan keputusan terhadap metode akuntansi yang diterapkan pada perusahaan yang mereka kelola. Sejalan dengan penelitian Siallagan dan Machfoedz (2006) dan Sari dan Riduwan (2013).

\section{Pengaruh kepemilikan institusional terhadap kualitas laba}

Jumlah kepemilikan saham oleh institusional menunjukkan tidak berpengaruh signifikan terhadap kualitas laba. Hasil menunjukkan bahwa variabel institusi kurang melakukan pengawasan yang ketat terhadap manajemen dalam melaporkan kondisi keuangan dan kinerja mereka. Pengawasan yang kurang ketat kurang dapat memperkecil peluang terjadinya tindakan manajemen laba yang dilakukan oleh manajer yang 
dapat merugikan investor. Dalam hal ini investor institusi nampaknya kurang mampu membawa manajer untuk melaporkan kondisi keuangan dengan laporan keuangan yang lebih berkualitas. Tidak adanya pengaruh dari kepemilikan institusi terhadap kualitas laba dinilai kurang dapat memberikan pengawasan terhadap perilaku manajer dalam melaporkan kondisi keuangannya. Sejalan dengan penelitian Sari dan Riduwan (2013) dan Lestari dkk (2014), semakin tinggi laba perusahaan, maka deviden yang didapat pemegang saham juga semakin tinggi.

\section{Pengaruh proporsi dewan komisaris independen terhadap kualiatas laba}

Demikian juga dengan keberadaan komisaris independen ternyata juga berpengaruh signifikan terhadap tindakan kualitas laba dengan arah positif. Satu penjelasanyang nampaknya relevan mengenai adanya keterkaitaannya variabel tersebut terhadap kualitas laba adalah disebabkan karena fungsi komisaris indepdeden sebagai fungsi kontrol terhadap tindakan manajemen yang optimal. Dengan peran dewan komisaris independen dalam melakukan fungsi pengawasan terhadap operasional perusahaan oleh pihak manajemen, proporsi dewan komisaris seharusnya dapat memberikan kontribusi yang efektif terhadap hasil dari proses penyusunan laporan keuangan yang berkualitas atau kemungkinan terhindar dari kecurangan laporan keuangan. Proporsi dewan komisaris yang terdiri dari anggota yang berasal dari luar perusahaan akan berperan dalam mempengaruhi kebijakan manajemen. Sejalan dengan penelitian Lestari dkk (2014) menunjukkan hasil bahwa proporsi dewan komisaris independen berpengaruh terhadap kualitas laba.

\section{Pengaruh komite audit terhadap kualitas laba}

Keberadaan komite audit diperoleh berpengaruh signifikan terhadap tindakan kualitas laba dengan arah positif. Hal ini menunjukkan bahwa jumlah dan keberadaan komite audit tersebut nampaknya memiliki perankomiteaudititudalammengubahkualitas laba. Keberadaan komite audit dimaksudkan untuk memantau perilaku manajemen dalam kaitannya dalam pembuatan laporan keuangan, sehingga dalam hal ini keberadaan komite audit diharapkan dapat memperkecil upaya manajemen untuk memanipulasi masalah data-data yang berkaitan dengan keuangan dan prosedur akuntansi, sehingga dapat meminimalkan upaya manajemen laba yang akan dilakukan oleh direksi dan jajarannya. Sejalan dengan penelitian Siallagan dan Machfoedz (2006) dan Lestari dkk (2014) hasil penelitiannya menunjukkan bahwa komite audit berpengaruh terhadap kualitas laba.

\section{Pengaruh kualitas laba terhadap nilai perusahaan}

Hasil penelitian mendapatkan bahwa ukuran kualitas laba berpengaruh signifikan terhadap PBV yang merupakan ukuran nilai perusahaan. Hal ini menunjukkan bahwa keberadaan kualitas laba berpengaruh pada kinerja keuangan perusahaan. Sebagaimana diidentifikasi bahwa kualitas laba ditunjukkan dengan melalui pengelolaan akrual dari keuangan perusahaan. Dengan demikian pengelolaan akrual yang dilaporkan oleh perusahaan berdasarkan identifikasi model modified Jones (Dechow) dilakukan dengan tidak melaporkan laba yang terdiskresi. Dengan kondisi demikian maka kepercayaan investor akan semakin besar sehingga nilai PBV dapat pula mengalami kenaikan. Sejalan dengan penelitian Siallagan dan Machfoedz (2006) dan Lestari dkk (2014) semakin berkualitas laba yang dilaporkan, maka akan meminimalkan kesalahan pembuatan keputusan para pemakai laporan keuangan, sehingga nilai perusahaan tetap terjaga.

\section{Pengaruh kepemilikan manajerial terhadap nilai perusahaan}

Jumlah kepemilikan manajerial 
menunjukkan berpengaruh signifikan terhadap nilai perusahaan karena manajemen akan meningkatkan kinerjanya yang berdampak pada peningkatan nilai perusahaan. Kebijakan perusahaan yang baik dapat memberikan peningkatan terhadap nilai perusahaan. Kepemilikan saham yang dimiliki manajerial semakin banyak maka akan meningkatkan nilai perusahaan dengan adanya manajemen di perusahaan dapat melakukan pengawasan di dalamnya sehingga laporan keuangan tidak ada yang akan dimanipulasi. Sejalan dengan penelitian Perdana dan Raharja (2014), Muryati dan Suardikha (2014), dan Lestari dkk (2014).

\section{Pengaruh kepemilikan institusional terhadap nilai perusahaan}

Jumlah kepemilikan saham oleh institusional menunjukkan tidak berpengaruh signifikan terhadap nilai perusahaan yang diukur PBV karena dinilai institusional hanya mementingkan keuntungan dan mendapatkan laba. Dengan hanya mementingkan pada laba saja institusional lebih mengutamakan kepentingan pribadi dari pada kepentingan umum. Sejalan dengan penelitian Lestari dkk (2014) yang menyatakan bahwa institusional yang hanya terfokus pada laba sekarang, dapat menarik sahamnya apabila perubahan laba dirasa tidak membawa keuntungan. Oleh karena institusional dalam perusahaan merupakan pemilik mayoritas, apabila saham ditarik akan mempengaruhi nilai saham secara keseluruhan.

\section{Pengaruh proporsi komisaris independen terhadap nilai perusahaan.}

Demikian juga dengan keberadaan komisaris independen ternyata juga berpengaruh signifikan terhadap tindakan nilai perusahaan dengan arah positif. Keberadaan komisaris independen yang tidak memiliki hubungan dengan keuangan, kepengurusan, kepemilikan saham yang mampu menilai secara obyektif. Sejalan dengan penelitian Lestari dkk (2014) yang menyatakan komisaris independen memiliki pengaruh terhadap kinerja manajemen agar lebih memaksimalkan kinerjanya dengan pengawasan yang lebih efektif. Komisaris independen juga menjadi penengah antara manajemen dengan pemegang saham sehingga konflik keagenan yang bisa menurunkan nilai perusahaan dapat diatasi.

\section{Pengaruh komite audit terhadap nilai perusahaan.}

Keberadaan komite audit diperoleh tidak berpengaruh signifikan terhadap nilai perusahaan dengan arah negatif. Komite audit dalam hal ini harus bersifat independen dalam hal independensi keanggotanya dan independensi fungsi audit. Jika karateristiknya tercapai komite audit mampu meningkatkan kinerja perusahaan yang akan berdampak pada nilai perusahaan yang meningkat. Sejalan dengan penelitian Perdana dan Raharja (2014) dan Muryati dan Suwardikha (2014) karena peningkatan komite audit justru akan menurunkan nilai perusahaan.

\section{Kualitas laba sebagai variabel intervening.}

Pengujian hipotesis mengenai pengaruh tidak langsung dari GCG terhadap nilai perusahaan PBV melalui kualitas laba menunjukkan bahwa mekanisme GCG komisaris independen dan komite audit berpengaruh sigifikan terhadap kualitas laba, sedangkan kualitas laba memiliki pengaruh signifikan tehadap nilai perusahaan PBV. Dengan demikian bahwa kualitas laba adalah variabel intervening pada hubungan antara corporate governance dan nilai perusahaan.

\section{SIMPULAN DAN SARAN}

\section{Kesimpulan}

Berdasar analisis di atas dapat diambil kesimpulan sebagia berikut:

1. Kepemilikan manajerial tidak memiliki pengaruh yang signifikan terhadap 
kualitas laba.

2. Kepemilikan institusional tidak memiliki pengaruh yang signifikan terhadap kualitas laba.

3. Dewan komisaris independen memiliki pengaruh yang positif dan signifikan terhadap kualitas laba. Semakin besar proporsi komisaris independen akan meningkatkan kualitas laba.

4. Komite audit memiliki pengaruh positif yang signifikan terhadap kualitas laba. Semakin besar anggota komite audit akan meningkatkan kualitas laba.

5. Kualitas laba memiliki pengaruh positif dan signifikan terhadap nilai perusahaan. Kualiats laba yang semakin baik akan meningkatkan nilai perushaan.

6. Kepemilikan manajerial memiliki pengaruh positif dan yang signifikan terhadap nilai perushaan.

7. Kepemilikan institusional tidak memiliki pengaruh dan signifikan terhadap nilai perusahaan.

8. Dewan Komisaris Independen memiliki pengaruh yang positif dan signifikan terhadap nilai perusahaan. Semakin besar proporsi komisaris independen di dalam perusahaan akan meningkatkan nilai perusahaan.

9. Komite audit tidak memiliki pengaruh yang signifikan terhadap nilai perusahaan.

10. Kualitas laba merupakan variabel intervening pada pengaruh GCG terhadap nilai perushaan.

\section{Saran}

Saran yang dapat diberikan berkaitan dengan hasil penelitian ini adalah sebagai berikut:

1. Kepemilikan manajerial berpengaruh negatif terhadap kualitas laba. Dalam hal ini perlunya mengurangi jumlah saham yang dimiliki manajemen dan total saham yang beredar sehingga akan berdampak pada kualitas laba.

2. Kepemilikan institusional berpengaruh negatif terhadap kualitas laba. Dengan demikian jumlah saham yang dimiliki institusional harus dikurangi dengan menjualnya kepada investor sehingga akan mempengaruhi kualitas laba.

3. Dewan komisaris independen berpengaruh positif terhadap kualitas laba. Dewan komisaris yang berasal dari luar perusahaan dan tidak ada hubunganya dengan anggota komisaris perusahaan mampu meningkatkan kualitas laba. Berarti jumlah dewan komisaris independen yang semakin banyak akan berpengaruh positif terhadap kualitas laba.

4. Komite audit berpengaruh terhadap kualitas laba. Semakin banyak jumlah komite audit maka akan berpengaruh terhadap kualitas laba. Oleh karena komite audit bertugas mengawasi jadi dengan adanya komite audit pengawasan semakin optimal di dalam perusahaan.

5. Kualitas laba memiliki pengaruh terhadap nilai perusahaan karena kualitas laba yang semakin baik maka akan meningkatkan nilai perusahaan. Investor lebih percaya dan berminat ketika perusahaan telah melakukan peningkatan kualitas laba dengan begitu akan meningkatkan nilai perusahaan.

6. Kepemilikan manajerial tidak ada pengaruhnya terhadap nilai perusahaan. Berbeda dengan jumlah saham yang dimiliki manajemen akan berpengaruh terhadap kualitas laba.

7. Kepemilikan institusional memiliki pengaruh terhadap nilai perusahaan. Jumlah saham yang dimiliki institusional mampu meningkatkan nilai perusahaan tetapi tidak berpengaruh terhadap kualitas laba. 
8. Dewan komisaris independen memiliki pengaruh terhadap nilai perusahaan dan kualitas laba semakin banyaknya jumlah dewan komisaris independen akan berpengaruh terhadap nilai perusahaan dan kualitas laba.

9. Komite audit tidak berpengaruh terhadap nilai perusahaan. Jumlah komite audit semakin banyak memberi pengaruh pada kualitas laba namun tidak pada nilai perusahaan.

10. Kualitas laba merupakan variabel intervening karena dinilai mampu menjadi variabel penghubung antara corporate governance dari nilai perusahaan.

\section{REFERENSI}

Brigham dan Houston. 2010. Dasar-Dasar Manajemen Keuangan. Jakarta: Salemba Empat.

Boediono, Gideon, SB. 2005. Kualitas Laba: Studi Pengaruh Mekanisme Corporate Governance dan Dampak Manajemen Laba dengan Menggunakan Analisis Jalur. Simposium Nasional Akuntansi VIII: 172194.

Ellili, Nejla Ould Daoud. 2011. Ownership Structure, Financial Policy and Performance of The Firm: US Evidence. Internasional Journal of Business And Management. Vol. 6 (10): 80-93.

Ferdinand, Augusty. 2011. Metode Penelitian Manajemen. Semarang: Badan Penerbit Universitas Diponegoro.

Forum For Corporate Governance in Indonesia. 2001. Peranan Dewan Komisaris dan Komite Audit dalam pelaksanaan Corporate Governance. Seri Tata Kelola Perusahaan. Jilid II. http://www.fcgi.org.id
Fuad, M, Christin H, Nurlela, Sugiarto, Paulus, Y.E.F. 2006. Pengantar Bisnis, Jakarta: PT Gramedia Pustaka Utama.

Gabrielsen G, Jeffrey D, Gramlish, and Thomas Plenborg. 2002. Managerial Ownership, Information Content of Earnings, and Discretionary Accruals In A Non-US Setting. Journal of Business Finance and Accounting. Vol. 29 (7) \& (8) Sept \& Okt.: 967988.

Ghozali, Imam. 2011. Aplikasi Analisis Multivariate dengan Program IBM SPSS 19. Semarang: Badan Penerbit Universitas Diponegoro.

Horne dan Wachowicz. 2014. PrinsipPrinsip Manajemen Keuangan. Jakarta: Salemba Empat

Khaliq, Abdul., Khairani, Siti dan Pratiwi Raisa. 2015. Pengaruh Kebijakan Deviden dan Good Corporate Governance (GCG) terhadap Nilai Perusahaan. Jurnal IJCCS http:// eprints.mdp.ac.id/1467/1/jurnal.pdf

Kharisma, N. 2013. Pengaruh Corporate Social Responsibility dan Good Corporate Governance terhadap Nilai perusahaan. Skripsi. http://d.library. uny.ac.id/opac/index.php? $\mathrm{p}=$ show detail\&id=9803

Klien, A.. 2002. Audit Committee, Board of Director Characteristics and Earnings Management, Journal Accounting and Economics. Vol. 33: 375400.

Lestari, Noviana Bekti, Khafid Muhammad, dan Anisykurlilah Indah. 2014. Pengaruh Good Corporate Governance terhadap Nilai Perusahaan dengan Kualitas Laba sebagai Variabel Intervening, Accounting Analysis Journal (AAJ). Vol. 3 (1). 
Muryati, Ni Nyoman Tri Sariri, dan Suardikha I Made Sadha. 2014. Pengaruh Corporate Governance pada Nilai Perusahaan. E-Jurnal Akuntansi. Universitas Udayana. Vol. 9 (2)

Nurhayati, Miranty dan Medyawati, Henny. 2012. Analisis Pengaruh Kinerja Keuangan, Good Corporate Governance dan Corporate Social Responsibility terhadap Nilai Perusahaan yang Terdaftar dalam LQ45 pada Tahun 2009-2011. Jurnal Akuntansi.

Perdana, Ramadhan Sukma dan Raharja. 2014. Analisis Pengaruh Corporate Governance terhadap Nilai Perusahaan. Diponegoro Journal of Accounting. Vol. 3 (3): 1-13.

Permanasari, Wien Ika. 2010. Pengaruh Kepemilikan Manajemen, Kepemilikan Institusional, dan Corporate Social Responsibility terhadap Nilai Perusahaan. Universitas Diponegoro.

Pertiwi, Tri Kartika dan Pratama, Ferry Madi Ika. 2012. Pengaruh Kinerja Keuangan, Good Corporate Governance Terhadap Nilai Perusahaan Food and Beverage. Jurnal Manajemen dan Kewirausahaan, Vol. 14 (2)

Prasinta, Dian. 2012. Pengaruh Good Corporate Governance terhadap Kinerja Keuangan. Accounting Analysis Jurnal (AAJ). Vol. 1 (2)

Priambodo, R Ervin A, dan Eko Supriyanto. 2007. Penerapan Good Corporate Governance sebagai Landasan Kinerja Perbankan Nasional. Usahawan, No. 05. Tahun XXXVI. Mei.

Purbopangestu, Hary Wisnu dan Subowo. 2014. Pengaruh Good Corporate Governance terhadap Nilai
Perusahaan dengan Corporate Social Responsibility sebagai Variabel Intervening. Accounting Analysis Journal (AAJ). Vol. 3 (3)

Sari, Enggar Fibria Verdana dan Riduwan Akhmad. 2013. Pengaruh Corporate Governance terhadap Nilai Perusahaan: Kualitas Laba sebagai Variabel Intervening. Jurnal Ilmu dan Riset Akuntansi. Vol. 1 (1)

Sartono, Agus. 2010. Manajemen Keuangan Teori dan Aplikasi. Yogyakarta: BPFE

Sekaran, Uma. 2006. Metode Penelitian untuk Bisnis. Jakarta: Salemba Empat.

Siallagan, Hamonangan dan Machfoedz, Mas'ud. 2006. Mekanisme Corporate Governance, Kualitas Laba, Nilai Perusahaan. Simposium Nasional Akuntansi 9. Padang.

Siregar, Silvia Veronica N.P., dan Siddharta Utama. 2005. Pengaruh Struktur Kepemilikan, Ukuran Perusahaan dan Praktik Corporate Governance terhadap Pengelolaan Laba (Earnings Management). Simposium National Akuntansi (SNA) VIII. Solo.

Subramanyam dan Wild. 2014. Analisis Laporan Keuangan "Financial Statement Analysis". Jakarta: Salemba Empat.

Sujoko dan Soebiantoro, Ugy. 2007. Pengaruh Struktur Kepemilikan Saham, Leverage, Faktor Intern dan Faktor Exstern terhadap Nilai Perusahaan. Jurnal Manajemen dan Kewirausahaan. Vol. 9 (1)

Sulistyanto, Sri. 2008. Manajemen Laba “ Teori dan Model Empiris". Jakarta: PT.Gramedia Widiasarana Indonesia.

Susanti, Anggraheni Niken. 2010. Analisis Pengaruh Mekanisme Corporate Governance terhadap Nilai 
Perusahaan dengan Kualitas Laba sebagai Variabel Intervening pada Perusahaan Manufaktur yang Terdaftar di Bursa Efek Indonesia Periode 2004-2007. Simposium Nasional Keuangan 1.

Rachmawati, Andri dan Hanung Triatmoko. 2007. Analisa Faktor-Faktor yang Mempengaruhi Kualitas Laba dan Nilai Perusahaan. Simposium Nasional Akuntansi (SNA) $X$. Makassar.

Vafeas, N. And Afxentiau, Z. 1998. The Association Between the SEC's 1992 Compensation Disclosure Rule and Executive Compensation Policy
Changes. Journal of Accounting and Public Policy. Vol. 17 (1): 27-54.

Wahyudi, Untung dan Hartini Prasetyaning Pawesri. 2006. Implikasi Struktur Kepemilikan terhadap Nilai Perusahaan dengan Keputusan Keuangan Sebagai Variabel Intervening. Simposium National Akuntansi (SNA) IX. Padang.

Wijaya, Anthony dan Linawati, Nanik. 2015. Pengaruh Kinerja Keuangan terhadap Nilai Perusahaan. Finesta, Vol. 3 (1)

http://www.bisnis.com

http://www.kompasiana.com

http://www.neraca.co.id 
